\title{
Spatial and temporal variation in cadmium body loads of four intertidal invertebrates from False Bay, South Africa
}

\author{
A.J. Reinecke*, N.P. Mdzeke ${ }^{\dagger} \&$ S.A. Reinecke \\ Department of Botany and Zoology, University of Stellenbosch, Private Bag X1, Matieland, 7600 South Africa \\ Received 9 March 2011. Accepted 22 August 2011
}

\begin{abstract}
Increasing urbanization and industrialization along the coastal areas of False Bay in South Africa can endanger coastal ecosystems because of increasing metal pollution. To obtain baseline data on contamination levels in the intertidal zone, cadmium (Cd) body loads of four invertebrate species were measured seasonally over a period of 15 months from different sites within the bay. Specimens of Tetraclita serrata (barnacle), Oxystele sinenses (periwinkle), Cymbula oculus (limpet) and Choromytilus meridionalis (mussel) were collected and analysed to determine temporal changes in Cd body burdens. Cd concentrations were also measured in water and sediments. Cd concentrations in the intertidal animals varied considerably between sampling sites and between seasons and also occasionally between species. All four species accumulated $\mathrm{Cd}$ in their bodies to levels several times higher than environmental concentrations. No significant difference could be shown between the Cd concentrations in the gastropod grazers and the filter-feeders. The highest mean body load of $\mathrm{Cd}(70.67 \mu \mathrm{g} / \mathrm{g}$ dry weight) for a single sampling occasion was measured in the sessile barnacles (T. serrata) collected at Rooi-Els. The highest mean Cd concentration $(11.95 \mu \mathrm{g} / \mathrm{g})$ for the bay as a whole was measured in the limpet $C$. oculus. Two-way analysis of variance indicated that spatial (location) rather than temporal (seasonal) factors affected Cd concentrations in the invertebrates. Cd concentrations in False Bay sometimes exceeded the norms or water quality standards.
\end{abstract}

Key words: Cd, invertebrate body burdens, marine pollution, seasonal variations.

\section{INTRODUCTION}

Pollution pressures on South African marine biodiversity were extensively studied until the 1980s but has become less 'fashionable' in recent years (O’Donoghue \& Marshall 2003). However such pressures associated with urbanization have continued to increase (Brown 1987) and are endangering coastal ecosystems where the biota may be stressed by point source discharges (sewage effluents, industrial wastes) and non-point source pollution (harbour activities, storm drainage, agricultural run-off) (Dabrowski et al. 2002). According to Zhang et al. (2005) heavy metals can be delivered to intertidal zones from the catchment via fluvial transport, atmospheric deposition, and/or local wastewater discharge. The question whether heavy-metal pollution in False Bay, South Africa, is posing a threat to the intertidal invertebrates remains important several years after previous studies had been completed (Van der Merwe et al. 1991; Taljaard et al. 2000) indicated the important role of the bay as a source of food and recreation. Apart from the fact that

^Author for correspondence. E-mail:ajr@sun.ac.za heavy metals are increasingly being introduced into marine environments by atmospheric deposition (Goh \& Chou 1997) and other anthropogenic inputs (Bu-Olayan \& Subrahmanyam 1998), human settlement and industrial activity in the area are still increasing (Mdzeke 2004).

Metals are toxic for marine biota above certain threshold concentrations. The embryos and juveniles of marine invertebrates are known to be sensitive to metal contaminants (Calabrese et al. 1973; Martin et al. 1981; Warnau et al. 1996; Chung et al. 2007). For example, spawning and subsequent embryonic development of squids are affected detrimentally by waterborne contaminants (Villanueva \& Bustamante 2006). Fertility and egg production are also affected (Seixas et al. 2005; Miramand et al. 2006; Villanueva \& Bustamante 2006).

Heavy metals such as cadmium (Cd) tend to be elevated in aquatic environments due to their persistent nature (Ankley et al. 1996). Cd is a relatively rare metal in the earth's crust and is not known to be essential to any organism (Burger 2008). It enters the environment from anthropogenic 
sources such as smelting works, battery manufacture, paints, corrosive coatings, fertilizers, and plastic stabilizers (Fielder \& Dale 1983). Natural sources include volcanic emissions, ocean spray, fires, and the release of metal-enriched particles from terrestrial vegetation (Burger 2008).

Cadmium is of high environmental concern because of its high toxicity, general usage, industrial production and, especially in South Africa, emissions from fossil fuel combustion and fertilizer usage. It is often present in seawater at trace levels but it is readily accumulated by marine invertebrates (Reinecke et al. 2008, 2009). Cellular damage may result from uptake of the $\mathrm{Cd}^{2+}$ ion in the tissues of marine organisms. It can substitute essential cations $\left(\mathrm{Zn}^{2+}\right.$ and $\left.\mathrm{Cu}^{2+}\right)$, which serve as co-factors in a number of enzymes (Nassiri et al. 1997). Molluscs, crustaceans and other marine invertebrates are known to accumulate high levels of heavy metals in their tissues and yet survive in polluted environments (Rainbow 1997). Their tolerance of high tissue levels of a metal at least partly depends on the ability of these organisms to 'regulate' the heavy metal cation concentration inside the cell and to accumulate excess metal in non-toxic forms (Rainbow 2002).

The suitability of benthic organisms as biomonitors of pollution stem from their sedentary lifestyle, long life spans that integrate contamination over time, and their differential levels of tolerance (Kiffney \& Clements 1993). Mussels such as Mytilus species have been used widely as biomonitors of pollution (Ramelow 1985). These organisms, however, are not found at all coastal locations, resulting in organisms such as barnacles and limpets also being considered as biomonitors. We therefore tested the hypothesis that these species in False Bay are also accumulators of $\mathrm{Cd}$ and may have the potential to serve as biomonitors. Among the crustaceans, the filter-feeding barnacles are the most sedentary and long-lived as well as strong net accumulators of trace metals (Rainbow 1995). They therefore fulfill several of the requirements to play a role in bioaccumulation monitoring. Although not sessile, limpets have a limited feeding range, making them also potentially suitable as biomonitors (Reinecke et al. 2008). Since the potential of several other invertebrate species to act as biomonitors has not yet been investigated fully, and it is generally agreed (Burger 2008) that animals from various trophic levels should be used to obtain a more complete picture of toxic risks involved, we surveyed several species. Since limpets and periwinkles are grazers while barnacles and mussels are filter-feeders, it raises the question whether differences in exposure scenarios between the grazing gastropods and the filter-feeders may result in differences in $\mathrm{Cd}$ bioaccumulation. We therefore also tested the hypothesis that filterfeeders in False Bay will have higher body burdens of $\mathrm{Cd}$ than grazers.

It is of major importance that pollution levels of metals such as $\mathrm{Cd}$ be monitored to provide information for the sustainable management of the area, given its role in the fisheries industry and recreation. Apart from the survey of water and sediment concentrations of Cd by Reinecke et al. (2008, 2009), which included experimental results on Cd uptake by the periwinkle, Oxystele tigrina, previous impact assessment studies on False Bay only focused on the effect of individual effluent discharges on the immediate surroundings, without looking at cumulative impacts (Taljaard et al. 2000). Limpets, mussels, barnacles, periwinkles and starfish (to a lesser extent) occur abundantly along the False Bay coastline (Griffiths \& Branch 1991), but there is little information on longer term Cd bioaccumulation and the relationship between body loads and environmental levels of $\mathrm{Cd}$ for different species, or how these concentrations may change in space and time due to changes in environmental conditions. The extent to which invertebrate species in False Bay may be affected in the long term is largely unknown. Reinecke et al. (2008; 2009) have shown experimentally that various limpet species and the periwinkle $O$. tigrina can accumulate $\mathrm{Cd}$ over a relatively short exposure period and that limpet species also differ in terms of their cellular sensitivities to the metal.

As is the case in several other South African coastal areas, tracking of changes in metal contamination is often hampered by a lack of comparative data (Vermeulen \& Wepener 1999). With that in mind the present study was conducted in the coastal waters of False Bay (Fig. 1) to obtain baseline information of $\mathrm{Cd}$ levels in intertidal invertebrates and their immediate surroundings. Seasonal effects are also critical in biomonitoring programmes (Mubiana et al. 2005). However, little is known about the influence of seasonal changes on metal content in organisms of the intertidal zone in False Bay.

The aim was therefore to obtain information over different seasons on $\mathrm{Cd}$ concentrations in the bodies of several intertidal invertebrate species living in different locations in False Bay, in addi- 


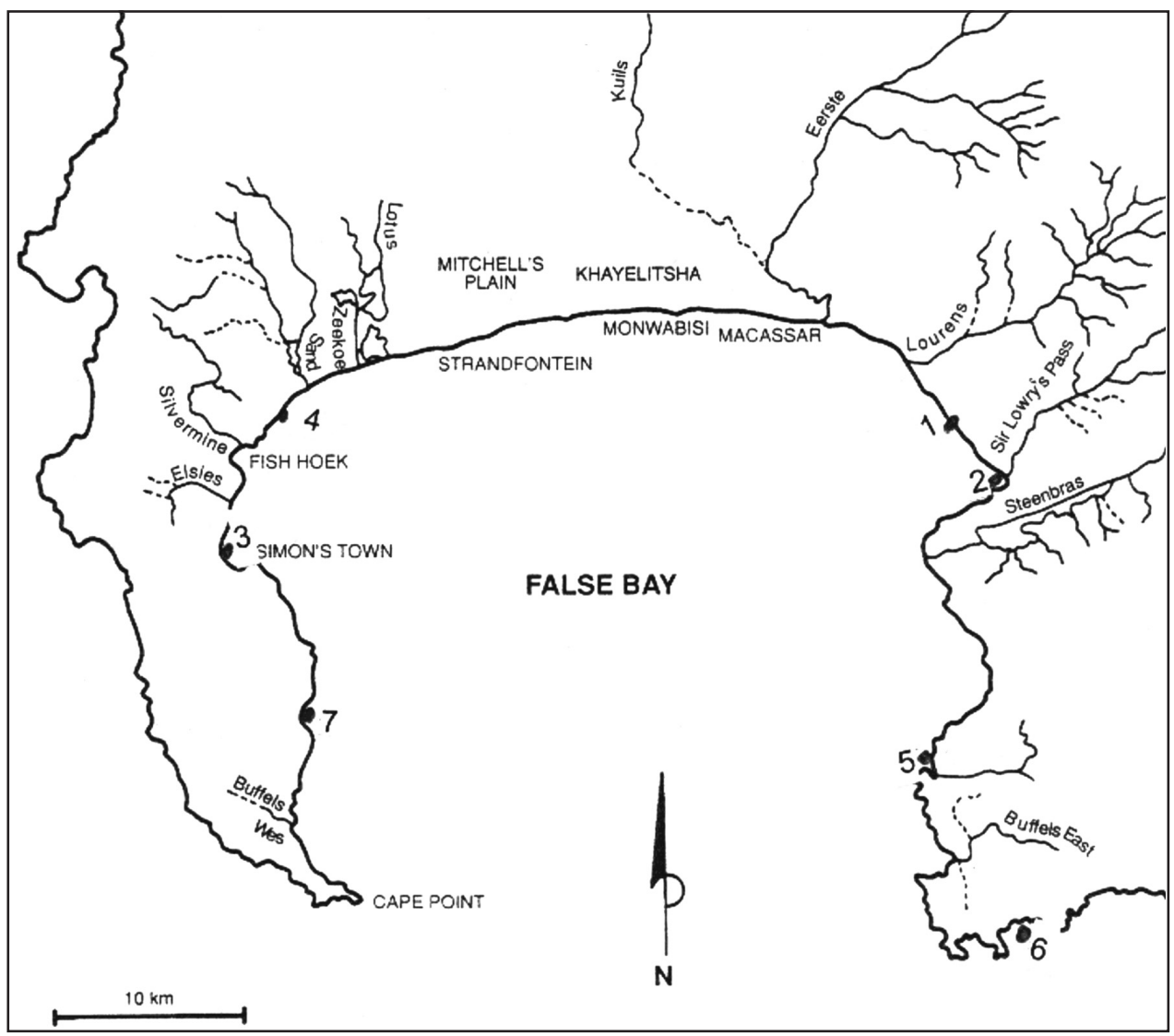

Fig. 1. Map of False Bay showing the seven sampling sites where intertidal invertebrates were collected. Site 1, Strand; 2, Gordon's Bay; 3, Glencairn; 4, Muizenberg; 5, Rooi-Els; 6, Kleinmond; 7, Miller's Point).

tion to that presented by Reinecke et al. (2009) for O. tigrina. A comparison of the Cd levels in these species with background levels of $\mathrm{Cd}$ in water and sediment can contribute to a better understanding of this metal's bioaccumulation potential in different marine invertebrates and a provide preliminary assessment of the threat $\mathrm{Cd}$ may pose to these organisms. It could provide an indication whether costly, long term monitoring of higher-level ecological effects is warranted.

\section{MATERIALS \& METHODS}

\section{Study area}

False Bay (Fig. 1), situated at $34^{\circ} 15^{\prime} \mathrm{S}, 18^{\circ} 40^{\prime} \mathrm{E}$, on the southern tip of Africa, is the largest true bay in South Africa (Heinecken et al. 1983; Mdzeke 2004). The waters of the bay are utilized extensively for the harvesting of fish and shellfish by commercial and subsistence fishermen (Van der Merwe et al. 1991) and for recreation and water sports (Taljaard et al. 2000). Human settlement along the bay's coastline has been increasing, with various recently completed housing projects or ones that are under way. The sites within the bay were selected based on land uses in the catchments and their potential to contribute towards pollution. Several of the sites were therefore close to river mouths while others were in the vicinity of water drainage canals.

\section{Animal sampling}

Specimens of the following four species were collected with permission of the coastal and marine authorities at the different localities where they occurred during different seasons (as indicated in Table 3 for each species) from July 2000 to July 2001 under the assumption that individuals within a certain class size were more or less of the same age (Anon. 1980): Tetraclita serrata (barnacle), Oxystele sinenses (periwinkle), Cymbula oculus (limpet) and Choromytilus meridionalis (black 
mussel). They were collected at the following times: July 2000 (winter), September 2000 (spring), December 2000 (summer), April 2001 (autumn) and July 2001 (winter).

Between 50 and 60 individuals of the barnacle T. serrata were collected from each of the seven sites at low tide. Twenty individuals of the limpet C. oculus of similar shell length $(4.0-5.5 \mathrm{~cm}$ range) were collected simultaneously from each of the same sites. The animals were dislodged from the rocky substrate with a stainless steel knife and placed in plastic buckets containing site water for transportation to the laboratory. To prevent the loss of body fluids, the barnacles were placed upside down in the buckets during transportation to the laboratory (Ireland 1974). Fifty specimens of $O$. sinenses were collected at each of three sites where this species coexists with O. tigrina (sites 1 , 3 and 7). Age-related and size-related differences in heavy metal accumulation (Bourgoin 1990) were also circumvented as far as possible by choosing individuals of similar shell length between 32 and $40 \mathrm{~mm}$. Thirty specimens of similar shell length (25-50 mm range) (Lobel et al. 1982) of the mussel C. meridionalis were collected seasonally over the same period (Table 3 ) in the intertidal zones at sites 4,5 and 6 . They were also dislodged from the rocks using a stainless steel blade.

\section{Sediment and water sampling}

Water and sediments were sampled at the different localities as described and reported by Mdzeke (2004) and Reinecke et al. (2009). Sediment and water samples were collected during five consecutive seasons between July 2000 and July 2001 at low tide at all the sites indicated in Fig. 1. Surface sediment samples were collected with a pre-cleaned plastic scoop $\left(0.1 \mathrm{~m}^{2}\right)$, with replicate samples collected at regular intervals of $10 \mathrm{~m}$ for up to $500 \mathrm{~m}$. The samples were placed in plastic bags on ice in cool boxes and transported to the laboratory where they were stored at $-20^{\circ} \mathrm{C}$ until analysis.

The water samples were collected simultaneously at $30 \mathrm{~cm}$ depth above the sediments using fivelitre plastic buckets. The buckets were also placed on ice. A litre of water from each of the water samples was filtered through a $0.45 \mu \mathrm{m}$ Whatman membrane filter, acidified with $1 \mathrm{ml}$ of concentrated nitric acid and frozen until further analysis. Concentrations in sediments are expressed as $\mu \mathrm{g} / \mathrm{g}$ (dry weight) and in water as $\mu \mathrm{g} / \mathrm{l}$.

\section{Heavy metal analysis}

The $\mathrm{Cd}$ analysis for water and sediment followed the procedure as described by Katz \& Jennis (1983) and Reinecke et al. (2009). The whole-body samples of invertebrates were oven-dried at $60^{\circ} \mathrm{C}$ for $48 \mathrm{~h}$, while the soft tissues and shells of the limpet and periwinkles were oven-dried separately. Aliquot samples $(0.2-0.5 \mathrm{~g})$ of each of five animals from each species were placed in test tubes and digested with $10 \mathrm{ml}$ of nitric acid overnight, heated at $40-60^{\circ} \mathrm{C}$ for $2 \mathrm{~h}$ in a test tube heating block, and then for a further $1 \mathrm{~h}$ at $110-120^{\circ} \mathrm{C}$. The digestates were allowed to cool before adding $1 \mathrm{ml}$ of perchloric acid and re-heating at $110-120^{\circ} \mathrm{C}$ until brown fumes appeared. They were allowed to cool again before adding $5 \mathrm{ml}$ distilled water and re-heating until white fumes appeared. The digestates were then left overnight, before filtering through a Whatman No. 6 filter paper and a 0.45 membrane micro-filter paper. A blank was prepared for each batch of samples. The Cd concentration in the animal samples was analysed using a flame atomic absorption spectrophotometer (Varian AA-1275) with acetylene-air flame. The metal concentrations in animals were expressed as $\mu \mathrm{g} / \mathrm{g}$ dry weight and the detection limit for $\mathrm{Cd}$ was $0.02 \mu \mathrm{g} / \mathrm{g}$, The extraction efficiency for animal samples was tested with bovine liver (NIST SRM 1577b) from National Institute of Standards and Technology (Gaithersburg, U.S.A.). It is certified for $4.84 \pm 0.03 \mu \mathrm{g} / \mathrm{g} \mathrm{Cd}$. AA-analysis of recovered Cd after acid digestion was $4.10 \mu \mathrm{g} / \mathrm{g}$, giving an acceptable efficiency of above $80 \%$.

\section{Rainfall, $p H$, temperature and conductivity}

The rainfall data (Table 1) for the sampling period was obtained from two weather stations of the South African Weather Bureau situated within the area of False Bay.

Water $\mathrm{pH}$ (Crison micro pH 2001 model), salinity and temperature (mean values presented in Table 2 ) were measured at all sites on sampling occasions using standard methodologies (Reinecke et al. 2009). The months in which sampling took place are presented in the tables.

\section{Statistical analysis}

Statistical analyses were performed using the Jandel Scientific Sigmastat 3.0 program. Metal concentrations in the soft tissues and shells of all the species were tested for normality using the Kolmogorov-Smirnov test. Non-parametric data were analysed using the Kruskal-Wallis ANOVA 
Table 1. Monthly rainfall $(\mathrm{mm})$ measured at two weather stations in the False Bay area during the sampling period of 2000 and 2001. (No rainfall during November, December, January and February). (Provided by the South African Weather Bureau.)

\begin{tabular}{lrrrr}
\hline & \multicolumn{2}{c}{ Strand } & & \multicolumn{2}{c}{ Simon's Town/Cape Point } \\
\cline { 2 - 3 } Month & 2000 & 2001 & & 2000 \\
\hline March & 15.8 & 1.2 & 22.8 & 0.4 \\
April & 8.0 & 38.2 & 11.2 & 26.8 \\
May & 85.6 & 136.2 & 16.2 & 49.0 \\
June & 79.6 & 44.8 & 30.6 & 41.4 \\
July & 77.8 & 197.6 & 25.4 & 106.4 \\
August & 86.0 & 93.6 & 23.4 & 61.2 \\
September & 74.0 & 63.6 & 36.4 & 28.8 \\
October & 5.0 & 55.6 & 2.4 & 21.8 \\
\hline
\end{tabular}

on ranks, followed by Dunn's test. The level of significance was $P<0.05$. For parametric data analyses of variance and Student's $t$-test were also used. Pearson correlation analysis was used to determine the relationship between water and whole-body $\mathrm{Cd}$ concentrations. In order to assess the roles of and interaction between the seasonal and spatial variables two-way ANOVA (MS-Excel) was used and descriptive statistics were also performed using MS-Excel.

\section{RESULTS}

\section{Water parameters}

The rainfall data (Table 1) for the study period indicated that precipitation was significantly higher during 2001 than during the previous year $(P<0.001)$, especially during July $(197 \mathrm{~mm}$ compared to $77 \mathrm{~mm}$ the previous year). It also varied considerably between different months and between different locations.

Measured water parameters are summarized in Table 2. The mean water temperatures for all sites ranged between $13.3^{\circ} \mathrm{C}$, measured during winter
2000 and $25.1^{\circ} \mathrm{C}$, measured during summer of 2000. There was a rapid decrease in temperature from summer to autumn 2001 at all the sites where temperature was measured. One-way ANOVA showed that these seasonal differences in temperature were highly significant $(P<0.001)$ within the same site. However, the spatial differences between sites were not prominent. The water $\mathrm{pH}$ ranged between 7.05 and 8.67 with higher maximum values measured during spring and summer compared to those measured during autumn and winter $(P<0.001)$ within the same sites. The mean water salinity measured at the different sites during the five seasons ranged from 28.40 to $35.24 \%$ and showed significant seasonal differences $(P<0.001)$ (not shown in the summarized data in Table 2) within sites, while overall there were no significant spatial differences.

Cadmium concentrations in water and sediment for the same sites and period under consideration have been published by Reinecke et al. (2009) and are presented graphically (Figs $2 \& 3$ ) to facilitate comparisons with body loads and to provide some general indication of $\mathrm{Cd}$ bioaccumulation potential.

Table 2. The ranges and mean values of the water parameters measured at seven sampling sites in False Bay during the study period.

\begin{tabular}{|c|c|c|c|c|c|c|}
\hline \multirow[t]{2}{*}{ Season } & \multicolumn{2}{|c|}{ Temp $\left({ }^{\circ} \mathrm{C}\right)$} & \multicolumn{2}{|c|}{$\mathrm{pH}$} & \multicolumn{2}{|c|}{ Salinity (\%॰) } \\
\hline & Range & Mean & Range & Mean & Range & Mean \\
\hline Winter 2000 & $13.3-14.8$ & 14.1 & $7.1-7.5$ & 7.2 & $29.2-35.0$ & 33.8 \\
\hline Spring 2000 & $16.0-18.2$ & 17.7 & $7.1-8.3$ & 7.9 & $30.1-35.2$ & 34.1 \\
\hline Summer 2000 & $18.4-25.0$ & 21.6 & $7.4-8.7$ & 8.2 & $31.0-35.2$ & 34.3 \\
\hline Autumn 2001 & $14.1-18.0$ & 15.7 & $7.3-7.8$ & 7.5 & $30.2-35.2$ & 34.3 \\
\hline Winter 2001 & $14.2-16.0$ & 15.0 & $7.1-7.8$ & 7.4 & $28.4-35.1$ & 33.8 \\
\hline
\end{tabular}




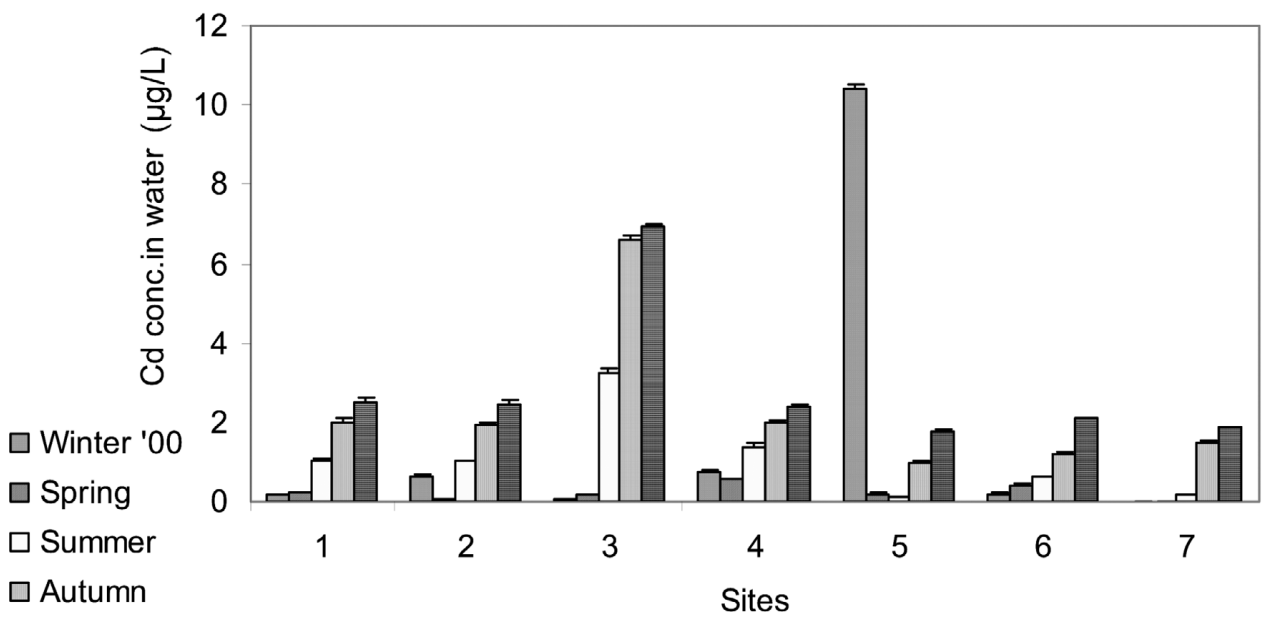

目 Winter '01

Fig. 2. Mean Cd concentrations in water samples $(\mu \mathrm{g} / \mathrm{l})$ from the different sites of the False Bay intertidal zone during five seasons. Site 1, Strand; 2, Gordon's Bay; 3, Glencairn; 4, Muizenberg; 5, Rooi-Els; 6, Kleinmond; 7, Miller's Point. (After Reinecke et al. 2009.)

The Cd concentrations in water samples were consistently higher at all but one site during the winter (July) 2001 survey when the rainfall was also very high. The exception was site 5 (Rooi-Els) when the water in the winter of 2000 had the highest concentrations. The water from site 3 (Glencairn) had the highest mean $\mathrm{Cd}$ concentration when comparing sites.

\section{Cd concentrations in intertidal invertebrates}

Mean Cd concentrations in the intertidal invertebrates collected at the sites in False Bay during different seasons are presented in Table 3. Detect- able concentrations measured during the whole sampling period ranged between $0.78 \mu \mathrm{g} / \mathrm{g}$ (dry weight) and the highest concentration of 70.67 $\mu \mathrm{g} / \mathrm{g}$ (dry weight) measured in the animal samples collected at Rooi-Els (site 5).

Comparison of $\mathrm{Cd}$ mean body concentrations obtained over all seasons and from all samples in the bay for a particular species indicated that the non-parametric data showed a statistically significant difference (Kruskal-Wallis test) $(P<0.001)$. Dunn's multiple comparison test confirmed that the limpet C. oculus $(11.95 \mu \mathrm{g} / \mathrm{g})$ had a significantly higher $(P<0.05) \mathrm{Cd}$ concentration than the periwinkle O. sinensis $(6.95 \mu \mathrm{g} / \mathrm{g})$, the mussel C. meri-

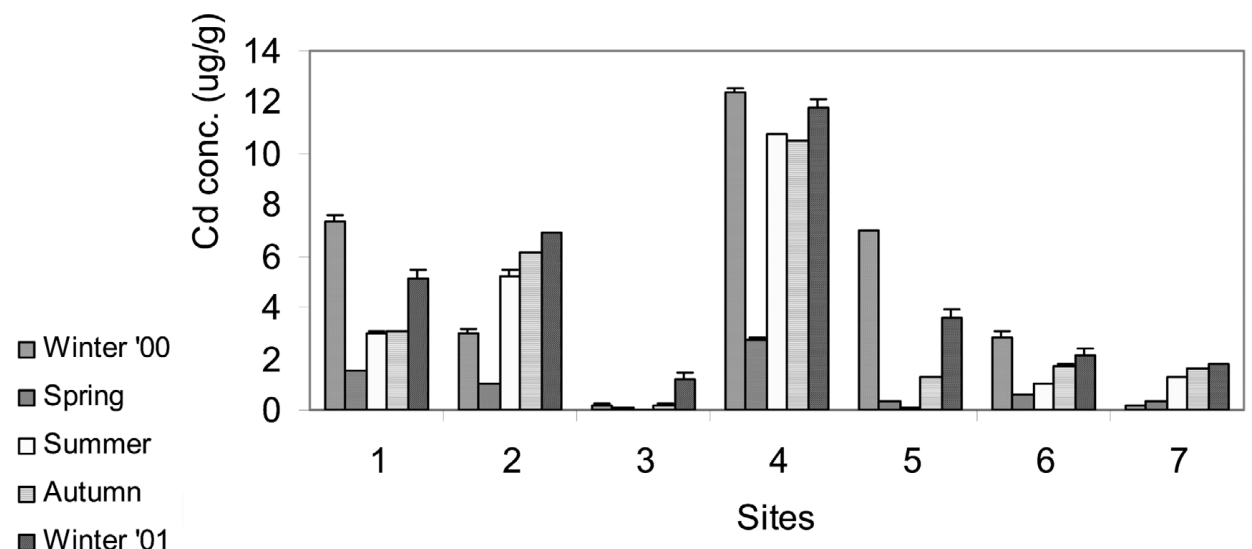

Fig. 3. Mean Cd concentrations ( $\mu \mathrm{g} / \mathrm{g}$, dry mass) measured during five seasons in the sediment samples from different sites along the False Bay intertidal zone. Site 1, Strand; 2, Gordon's Bay; 3, Glencairn; 4, Muizenberg; 5, Rooi-Els; 6, Kleinmond; 7, Miller's Point. (After Reinecke et al. 2009.) 
Table 3. Seasonal and overall temporal means \pm standard deviation (S.D.) of cadmium concentrations ( $\mu \mathrm{g} / \mathrm{g}$, dry weight) measured during different seasons in the soft tissue of four intertidal species in False Bay. Within columns significant $(P<0.05)$ temporal differences are indicated by common alphabetical superscripts. Within rows significant differences between species are indicated by common numerical superscripts. (BDL = below detection limit $<0.02 \mu \mathrm{g} / \mathrm{g}$ ). Figures in brackets indicate the sites sampled. Site 1, Strand; 2, Gordon's Bay; 3, Glencairn; 4, Muizenberg; 5, Rooi-Els; 6, Kleinmond; 7, Miller's Point).

\begin{tabular}{lcccc}
\hline Species: & $\begin{array}{c}\text { O. sinensis } \\
(1,3,5)\end{array}$ & $\begin{array}{c}\text { T. serrata } \\
(1-7)\end{array}$ & $\begin{array}{c}\text { C. oculus } \\
(1-7)\end{array}$ & $\begin{array}{c}\text { C. meridionalis } \\
(4,5,6)\end{array}$ \\
\hline Weason & $3.41 \pm 1.9$ & $14.72 \pm 24.8$ & $14.77 \pm 9.9$ & $7.57 \pm 7.5$ \\
Spring (Sept) & $8.13 \pm 7.9$ & $11.84 \pm 25.2$ & $10.94 \pm 4.3$ & $3.17 \pm 4.0$ \\
Summer (Dec) & $0.91 \pm 0.7$ & $7.02 \pm 15.5$ & $5.99 \pm 4.0$ & $3.92 \pm 3.8$ \\
Autumn (April 2001) & $\mathrm{BDL}^{\mathrm{a}}$ & $6.40 \pm 6.8$ & $12.71 \pm 8.7$ & $5.34 \pm 3.3$ \\
Winter (July) & $22.65 \pm 5.3^{\mathrm{a}}$ & $8.36 \pm 8.5$ & $15.32 \pm 8.5$ & $6.35 \pm 3.4$ \\
All seasons mean \pm S.D. & $6.95 \pm 9.3^{12}$ & $9.68 \pm 17.2^{14}$ & $11.95 \pm 7.8^{1}$ & $5.27 \pm 4.3^{13}$ \\
Range & $0-28.7$ & $0-70.7$ & $5-31.5$ & $0.6-16.3$ \\
\hline
\end{tabular}

dionalis $(5.27 \mu \mathrm{g} / \mathrm{g})$ and the barnacle T. serrata $(9.68$ $\mu \mathrm{g} / \mathrm{g})$. The mean Cd concentrations for all seasons in the latter three species did not differ significantly from each other.

Testing for differences between sites for all species occurring in the same sites (for all samples) showed that the data for $O$. sinensis, T. serrata and C. occulus, all three occurring in Strand, Glencairn and Miller's Point, were non-parametric and no statistically significant differences were found between any of the sites, as shown by the KruskalWallis test $(P=0.981)$.

In a similar comparison of the non-parametric data for T. serrata, C. occulus and C. meridionalis, all three species occurring in Muizenberg, Rooi-Els and Kleinmond, the Kruskal-Wallis test showed a statistically significant difference $(P<0.013)$ between the sites.

Dunn's multiple comparison test showed a significant difference between the mean body concentrations for all three species found in Muizenberg $(5.89 \mu \mathrm{g} / \mathrm{g})$ and Rooi-Els $(22.77 \mu \mathrm{g} / \mathrm{g})$ and also between Rooi-Els and Kleinmond $(9.65 \mu \mathrm{g} / \mathrm{g})(P<0.05)$.

Comparing the non-parametric data for all the samples of T. serrata and C. occulus that were both sampled at all seven sites in Kalk Bay, the Kruskal-Wallis test indicated statistical differences $(P<0.001)$. Dunn's test revealed that the mean body concentrations of these two species found at Rooi-Els $(30.43 \mu \mathrm{g} / \mathrm{g})$ differed statistically significantly from those found at Strand $(7.43 \mu / \mathrm{g})$, Gordon's Bay $(4.99 \mu \mathrm{g} / \mathrm{g})$, Glencairn $(4.46 \mu \mathrm{g} / \mathrm{g})$ and Muizenberg $(5.74 \mu \mathrm{g} / \mathrm{g})(P<0.05)$.

We also investigated the differences in mean $\mathrm{Cd}$ body concentrations for all samples, irrespective of sites, between the seasons for every species separately. The data for $C$. meridionalis passed the test for normality and a one-way ANOVA showed that for this species there were no statistically significant differences between the seasons $(P=0.781)$ with mean concentrations varying between 3.17 and $7.57 \mu \mathrm{g} / \mathrm{g} \mathrm{Cd}$.

The data for $O$. sinensis (irrespective of sites) were non-parametric and the Kruskal-Wallis indicated a statistically significant difference $(P=0.016)$. Dunn's test only showed a statistically significant difference $(P<0.05)$ between Autumn (no Cd detected) and Winter $2001(22.65 \mu \mathrm{g} / \mathrm{g})$ for this species.

For T. serrata (irrespective of sites) the mean Cd concentrations between seasons varied between 6.43 and $14.73 \mu \mathrm{g} / \mathrm{g}$ but no statistically significant differences were found between the different seasons.

The data for C. oculus (irrespective of sites) passed the test for normality and a one-way ANOVA showed that there were no significant differences in $\mathrm{Cd}$ body concentrations between the seasons $(P=0.167)$. For this species the mean $\mathrm{Cd}$ body concentrations varied between 5.99 and $15.32 \mu \mathrm{g} / \mathrm{g}$ during the different seasons.

A comparison of the mean $\mathrm{Cd}$ concentrations found in a species over all seasons (for all the different sites in which such a species occurred) showed that for $O$. sinensis there were no statistically significant differences between Strand $(4.97 \mu \mathrm{g} / \mathrm{g})$, Glencairn $(7.28 \mu \mathrm{g} / \mathrm{g})$ and Miller's Point $(8.59 \mu \mathrm{g} / \mathrm{g})$ In the case of T. serrata the barnacles sampled at Rooi-Els $(45.69 \mu \mathrm{g} / \mathrm{g})$ had a significantly 
Table 4. A comparison of mean cadmium concentrations ( $\mu \mathrm{g} / \mathrm{g} \pm$ S.D.) (dry weight) in the shells and soft tissue of Oxystele tigrina (from Reinecke et al. 2009), Oxystele sinensis and Choromytilis meridionalis measured at three different sites in False Bay during different seasons.

\begin{tabular}{|c|c|c|c|c|c|c|c|c|c|}
\hline & \multicolumn{3}{|c|}{$\begin{array}{c}\text { Summer } 2000 \\
\text { (December) }\end{array}$} & \multicolumn{3}{|c|}{$\begin{array}{c}\text { Winter } 2000 \\
\text { (July) }\end{array}$} & \multicolumn{3}{|c|}{$\begin{array}{l}\text { Spring } 2000 \\
\text { (September) }\end{array}$} \\
\hline & 0. tigrina & 0. sinensis & C. meridion & 0. tigrina & 0. sinensis & C. meridion & 0. tigrina & 0. sinensis & C. meridion \\
\hline Shell & $7.0 \pm 10.0$ & $1.4 \pm 1.4$ & $7.36 \pm 5.5$ & $1.6 \pm 1.5$ & $0.6 \pm 0.3$ & $3.1 \pm 2.9$ & $0.9 \pm 0.6$ & $\mathrm{BDL}$ & $0.9 \pm 0.7$ \\
\hline Soft & $14.5 \pm 15.1$ & $3.4 \pm 1.9$ & $7.6 \pm 7.5$ & $3.6 \pm 1.2$ & $7.7 \pm 8.4$ & $1.1 \pm 0.7$ & $3.2 \pm 4.0$ & $0.9 \pm 0.7$ & $3.9 \pm 3.8$ \\
\hline
\end{tabular}

higher mean concentration than those sampled at Glencairn $(2.44 \mu \mathrm{g} / \mathrm{g})$, Gordon's Bay $(2.04 \mu \mathrm{g} / \mathrm{g})$, and Miller's Point $(2.77 \mu / \mathrm{g})$ but were not significantly different from those sampled at Strand $(3.06 \mu \mathrm{g} / \mathrm{g})$, Muizenberg $(4.88 \mu / \mathrm{g})$ and Kleinmond $(6.86 \mu \mathrm{g} / \mathrm{g})$. In the case of C. oculus the parametric data were subjected to the Kruskal-Wallis test which suggested one-way ANOVA followed by the Holm-Sidak test. This indicated that the mean body concentration at Rooi-Els $(15.18 \mu \mathrm{g} / \mathrm{g})$ was significantly higher $(P<0.05)$ than those from Glencairn $(6.49 \mu \mathrm{g} / \mathrm{g})$, Muizenberg $(6.60 \mu \mathrm{g} / \mathrm{g})$ and Gordon's Bay $(7.94 \mu \mathrm{g} / \mathrm{g})$. The concentration at Miller's Point $(15.69 \mu \mathrm{g} / \mathrm{g})$ was also significantly higher than at Glencairn $(6.49 \mu \mathrm{g} / \mathrm{g})$. The concentration at Miller's Point was also significantly higher than at Muizenburg.

The data for the mussel C. meridionalis were parametric and the Kruskal-Wallis test also suggested a one-way ANOVA followed by the Holm-Sidak test. In this case only the mean concentration found in the mussels from Rooi-Els $(7.7 \mu \mathrm{g} / \mathrm{g})$ was significantly higher than that from Kleinmond $(2.16 \mu \mathrm{g} / \mathrm{g})$ but did not differ significantly from the Muizenberg $(6.20 \mu \mathrm{g} / \mathrm{g})$ concentration. The data for the latter two sites showed no statistical differences $(P<0.781)$.

The possible influence of spatial and seasonal factors and their interactions as independent variables on the $\mathrm{Cd}$ concentrations were assessed with two-way ANOVA for all species and showed a highly significant $(P=0.0005)$ spatial effect of the sampling sites while there was no significant difference between seasons. No significant interaction between sites and seasons could be demonstrated. Analysing the results for each species separately indicated that for C. oculus and T. serrata (both species sampled at all seven sites) there was also a significant effect of sites but not of seasons. The opposite was true for $O$. sinensis where seasons did show a significant effect $(P=0.001)$. For C. meridionalis no significant effect of either sites or seasons could be demonstrated.

Overall the mean Cd body concentrations in all the species were significantly higher $(P<0.05)$ than in the water. This was also true for most seasons at all sampling sites, although it varied between 10 times higher and more than 300 times higher at the Rooi-Els site between winter and spring for the barnacles, where the biggest differences were measured. The Pearson correlation analysis showed that overall there was a significant positive correlation between the concentrations of $\mathrm{Cd}$ in the water and the body samples $(P<0.001$, $r=0.97$ ) of the barnacles.

\section{Comparison of $\mathrm{Cd}$ in soft tissues and shells}

A comparison between the mean Cd concentrations in the soft tissues and shells for three of the intertidal species sampled during three different seasons in 2000 is presented in Table 4.

The data for O. tigrina, sampled over the whole period was subjected to the Student's $t$-test which indicated no significant difference $(P=0.058)$ between the mean concentrations for soft tissue $(6.42 \mu \mathrm{g} / \mathrm{g})$ and the shell $(3.01 \mu \mathrm{g} / \mathrm{g})$. In the case of $O$. sinensis there was a statistical difference $(P=0.010)$ between the concentration in the soft tissue $(4.03 \mu \mathrm{g} / \mathrm{g})$ and the shell $(0.63 \mu \mathrm{g} / \mathrm{g})$. The all-seasons data for the mussel, C. meridionalis, passed the normality test and the $t$-test showed no statistical difference $(P=0.453)$ between the mean Cd concentration in the shell $(3.79 \mu \mathrm{g} / \mathrm{g})$ and the soft tissue $(4.89 \mu \mathrm{g} / \mathrm{g})$. Comparison of concentrations between soft tissues and shells within specific seasons showed no significant differences.

\section{DISCUSSION}

Comparison of the $\mathrm{Cd}$ body concentrations with the water and sediment concentrations indicated that this metal is strongly accumulated by all four intertidal invertebrates from their surrounding environment. Reinecke et al. (2009) showed that $\mathrm{Cd}$ levels in the water during the same period as 
when the invertebrate specimens were collected for this study, varied considerably in space and time. These concentrations could not be compared directly to previous measurements of $\mathrm{Cd}$ in the intertidal zone of the bay since previous reports, such as that of Taljaard et al. (2000), did not provide accessible quantitative data in the mainstream scientific literature. Of all the invertebrates we surveyed, individual specimens of the barnacles collected from site 5 (Rooi-Els) accumulated the highest $\mathrm{Cd}$ concentrations at certain sampling times, indicating that these organisms may be strong net accumulators of $\mathrm{Cd}$, as found elsewhere for barnacles (Beyer et al. 1996; Ruelas-Inzunza \& Paez-Osuna 1998). However, looking at mean Cd levels in individual species (for all seasons and all sites) the limpets accumulated significantly more $\mathrm{Cd}$ than all other species. The ability of limpets to accumulate $\mathrm{Cd}$ from their environment was also demonstrated in previous studies in the Bristol Channel (Shore et al. 1975).

By lumping the data together for all species occurring in the same sites, we found that the animals sampled at Rooi-Els had significantly more $\mathrm{Cd}$ in their bodies than the same species at Muizenberg and Kleinmond. This seems to be an indication that differences in contamination levels occurred between sites and variation in contamination incidents could have occurred over time.

Barnacles are sessile and the accumulated $\mathrm{Cd}$ probably represents integrated contamination levels at the same locality over an extended period of time (Schulz-Baldes 1977). No corresponding, consistently high concentrations of $\mathrm{Cd}$ were measured over all the seasons in sediments or water (Mdzeke 2004; Reinecke et al. 2009) at Rooi-Els. The sediment and water Cd concentrations measured during the winter of 2000 were however much higher at Rooi-Els than for other seasons and sites. The mean $\mathrm{Cd}$ body loads of the barnacles at this site did not change initially but decreased during subsequent surveys as longerterm elimination could have taken place. These results show that one contamination incident causing high Cd levels in the environment, could later result in long-term biological exposure.

The findings support our first hypothesis that the barnacle T. serrata and the limpet $C$. oculus may have the potential to be used for the field biomonitoring of $\mathrm{Cd}$ contamination since they accumulated $\mathrm{Cd}$ in their bodies. Limpets represent a different feeding type than mussel species that are normally advocated for biomonitoring purposes.
They are also reasonably sessile or fairly localized and are not too sensitive (Reinecke et al. 2008).

The four invertebrate species collected and analysed during this study represent very different intertidal habitats and feeding modes (Day 1969; Branch et al. 2005). The sessile barnacles, T. serrata, are found on rocky shores where they face strong wave action as well as dry periods when the tide is low. Limpets such as C. oculus, occur on the rocky shores where they are exposed to wave action as well as dry periods, but they show some mobility as grazers foraging on algae on the rocks. Their ability to attach very strongly to the rock surface may prevent them from being continuously exposed to contaminated water. Filter-feeding mussels, C. meridionalis, are more permanently attached to the rocks and represent yet a different zone in the shore stratification. Periwinkles, O. sinensis, occur in pools of the rocky shore and remain submerged most of the time during low tide although the salinity in the pools may change as a result of evaporation or rain. They can, however, withdraw their bodies and seal the opening of the shell, thereby preventing exposure. As we hypothesized, differences in exposure scenarios could therefore be expected due to habitat differences, behavioural differences and differences in feeding types and could, at least partly, explain observed differences in the $\mathrm{Cd}$ body loads of different species. According to Burger et al. (2003) differences in the trophic levels of species may provide some explanation for the large variations that are found between species with very different lifestyles and occupying very different habitats as well as different ecological niches.. The activity rhythms of limpets and their adapted behaviour to osmotic stress, predation and wave action (Branch \& Cherry 1985) may render them less exposed for certain periods of the day to environmental contaminants than other species that are continuously active and submerged or at least surrounded by contaminated water for longer periods. Therefore we expected the filter-feeding barnacles and mussels to be exposed differently than the grazing periwinkles and limpets. However, in spite of these differences between species, our data did not support the hypothesis and did not allow us to draw a clear distinction between mean $\mathrm{Cd}$ body loads over the duration of the observation period between the grazing gastropods on the one hand and the filter-feeding mussels and barnacles on the other. Given the high degree of individual variation found in $\mathrm{Cd}$ 
body loads between sampling sites and occasions, more intensive sampling and a more specific experimental design may be required before such a distinction can be made. A difference in contamination levels and the frequency or duration of such incidents at different sampling locations and seasons could also mask the expected differences between these groups.

We also compared the metal concentrations in the invertebrates from False Bay with those found in brown mussels from Richards Bay Harbour (Greenfield et al. 2011) and mussels from other known metal contaminated regions. Mean $\mathrm{Cd}$ levels in all invertebrates from False Bay were greater than those found by Greenfield et al. (2011) for Perna perna and Liu \& Kueh (2005) for Perna viridus in Victoria Harbour, Hong Kong. However, all the maximum concentrations we measured in mussels from False Bay were below the metal concentrations recorded for mussels (Mytilus edulis) from the metal polluted Western Scheldt Estuary in The Netherlands (Mubiana et al. 2005).

Decrease in Cd content during summer in some invertebrates may be related to the spawning process, while increases during winter may be related to gonadal development which is often accompanied by metal accumulation (Regoli 1998). According to various authors (Powell \& White 1990; Blackmore 1999), decreased salinity tends to increase heavy metal uptake and accumulation. Although no analysis was done to confirm such a correlation in our study, we did find indications that a positive relationship between salinity and $\mathrm{Cd}$ concentrations in the soft tissues may exist. When the rainfall was higher during winter months, salinity and $\mathrm{pH}$ were also lower but the $\mathrm{Cd}$ body content was higher than in summer, probably because the lower $\mathrm{pH}$ and salinity in combination could have greatly increased the bioavailability of $\mathrm{Cd}$. This would be in agreement with the findings of Hops (1990) that salinity has a strong influence on the accumulation of metals by bivalves.

In this study we looked at seasonal differences in general, but did not specifically attempt to assess the complex role of individual environmental factors such as salinity, temperature and $\mathrm{pH}$ in influencing contamination levels in intertidal species. These factors may, however, play an important role. The variable seasonal values in temperature in the False Bay area are due to the extent and shallow nature of the bay (Grindley \& Taylor 1970), as well as the prevailing southerly and northwesterly winds on the projecting points of the bay (Fig. 1) (Day 1970). The Benguela current from the Atlantic coast rounds Cape Point and enters the bay, causing upwelling along the western side as far as site 7 (Miller's Point). As summer advances and the southeasterly winds become stronger, pools of the Agulhas current with surface temperatures between 19 and $20^{\circ} \mathrm{C}$ can blow into the bay (Day 1970). This may account for the lower temperatures we recorded along the western side at sites 3,4 and 7 . Changes in temperature are known to trigger spawning in many molluscs (Branch 1974), which could potentially influence body metal content. There may also be other factors involved. Paez-Osuna et al. (1995) have also shown that other metals such as Zn can influence gonadal development and accumulation of trace metals.

According to Regoli (1998), the development and maturation of gonads in Patella oculus (now Cymbula oculus) occurs during late summer and early autumn, while Branch (1974) proposed a bi-annual spawning in this limpet species, which occurs during March or April (autumn), and September (spring). During this time, there is a progressive build-up of gonad weight until spawning occurs. Any significant decrease in heavy metal concentrations during summer may also be related to the metal reduction that accompanies the spawning process, which in turn is influenced by environmental conditions. We found a significant increase in the heavy metal concentrations in $O$. sinensis during the colder autumn and winter periods, which may be related to the gonad maturation process that continues to occur while temperatures, are dropping (Branch 1974).

Testing with two-way ANOVA for the combined effects of spatial and temporal factors on all species sampled, showed that location rather than season influenced the accumulation of $\mathrm{Cd}$. Referring to our findings at the different sites, we surmise that contamination incidents and levels at some sites, such as for example Rooi-Els, could have been higher and with a long enough duration to show such differences. Alternatively local environmental conditions could have affected bioavailability and therefore uptake of $\mathrm{Cd}$ differently at different sites.

The seasonal change in the wind directions in False Bay from southeasterly to northwesterly during summer and winter respectively (Darracott \& Watling 1975), combined with the fluctuation in 
rainfall, may to some extent account for seasonal variations in $\mathrm{Cd}$ concentrations in the water and therefore also in the intertidal invertebrates. Increased runoff associated with the higher amount of rainfall during winter may result in the mobilization of the metal from diffuse sources (Neal et al. 2000) and can contribute to the higher concentrations of $\mathrm{Cd}$ in the sediments during winter. Local dilution effects causing decreased concentrations of $\mathrm{Cd}$ available for uptake could have occurred (Mdzeke 2004). However, lower water salinities were recorded at sites 1, 5 and 6 and may be an indication of the freshwater inflows from the Lourens, Rooi-Els and Kleinmond Rivers, which open into the bay at these sites respectively. According to Hops (1990), a reduction in salinity leads to a reduction in the chloro-complexation of heavy metals such as $\mathrm{Cd}$, resulting in increased bioavailability of the free $\mathrm{Cd}$ ions. If this also affected the extractability of $\mathrm{Cd}$, it could partially explain the higher concentration of $\mathrm{Cd}$ measured in the sediment samples from these sites (Reinecke et al. 2009) when a low salinity regime occurred during winter. Salinity can have a strong influence on the bioavailability and accumulation of heavy metals by invertebrates, with a reduction in salinity leading to an increase in Cd uptake and accumulation into animal tissues (Rainbow et al. 2000). In the present study, the lowest water salinity measured at Strand (site 1) coincided with the highest $\mathrm{Cd}$ concentration in the soft tissues of the limpet $C$. oculus while the highest water salinity at Glencairn (site 3) was associated with the lowest $\mathrm{Cd}$ concentrations (Table 3).

The question as to the exact origin of the $\mathrm{Cd}$ found in False Bay's marine invertebrates cannot be answered easily because of the many diverse sources that could potentially contribute. Agricultural and other industrial activities in the catchment area of False Bay are contributing to the $\mathrm{Cd}$ entering the bay. $\mathrm{Cd}$ in the water and sediments (Reinecke et al. 2009) of the bay may have been the result of sources such as the chemical factory that was situated near site 1 (Strand). This plant did discharge its effluent intermittently into False Bay until the year 2000 (Taljaard et al. 2000). Owing to the closure of this facility, one would have expected the threat of increasing or continued contamination from this site to have diminished. The levels of $\mathrm{Cd}$ in water and sediments may also have been the result of municipal wastewater from industrial discharge or sewage outfalls and storm water outlets which discharge effluent and road runoff directly into the bay (Mdzeke 2004; Reinecke et al. 2009). Normally a relatively small amount of the $\mathrm{Cd}$ in soil is transferred to water, but in the long run the $\mathrm{Cd}$ entering the bay via surface water can accumulate more quickly in the sediments than in biota (Huckabee \& Blaylock 1973). Bioavailability of $\mathrm{Cd}$ for uptake by animals also varies depending upon the chemical form, environmental conditions and the nature of the medium. Physico-chemical factors such as temperature and $\mathrm{pH}$ influence the uptake of $\mathrm{Cd}$ by biota; increasing $\mathrm{pH}$ increases the susceptibility of invertebrate and amphibian larvae to $\mathrm{Cd}$ toxicity (Leuven et al. 1986; Bervoets \& Blust 2000). Cadmium toxicokinetics in animals are also affected by their age, sex and nutritional status and behaviour.

Marine invertebrates are known to incorporate heavy metals into their calcareous shells by displacing the $\mathrm{Ca}$ in the crystalline structure (Chinchon et al. 2000). We found that only O. sinensis accumulated significantly more $\mathrm{Cd}$ in the soft tissues than in the shells (Table 4) Herwig et al. (1989) found that after three weeks of exposure, the shell concentrations reached a plateau, suggesting that $\mathrm{Cd}$ storage via the adsorption process can be limited when it eventually becomes saturated.

Evidence of negative biological effects on invertebrates resulting from metal pollution has been documented for the heavily polluted Scheldt Estuary in Europe (De Wolf et al. 2000, 2005; Wepener et al. 2008). Any effort to interpret the ecotoxicological risks to invertebrates associated with $\mathrm{Cd}$ concentrations in False Bay will have to take cognizance of various complicating factors. The $\mathrm{Cd}$ concentrations in the different samples varied considerably according to the time of sampling and collection site, limiting sound interpretation. Furthermore, there were variations in environmental parameters, which will have to be monitored more accurately, and regularly over several seasons before attempting to develop reliable predictive models for $\mathrm{Cd}$ ecotoxicity in False Bay. As pointed out by Reinecke et al. (2009) these factors will influence Cd's bioavailability and consequently the uptake by invertebrates and the resultant toxicity. The mere fact that $\mathrm{Cd}$ concentrations sometimes exceeded the norms or water quality standards (Fatoki \& Mathabhata 2001) does therefore not automatically serve as a conclusive indication of higher ecological risk (Posthuma et al. 2006). Conclusions on ecological risks will require more reliable measurements of 
ecological effects on population and community level that could be linked, with the required causality, or at least with a higher degree of certainty, to the presence of $\mathrm{Cd}$ concentrations.

Given the known hazards associated with $\mathrm{Cd}$ exposure, one should nevertheless, in accordance with the so-called precautionary principle, act preventatively by minimizing $\mathrm{Cd}$ input into False Bay whilst continuing to monitor not only $\mathrm{Cd}$ levels but also ecological effects carefully. Even a superficial comparison of $\mathrm{Cd}$ concentrations in sediment and water with those in the animal bodies provides enough evidence that this heavy metal can accumulate to levels that may pose a threat to some of the intertidal species.

\section{ACKNOWLEDGEMENTS}

This study was made possible by a grant from the National Research Foundation to the principal author. Any opinions, findings and conclusions or recommendations expressed in this material are those of the authors. This paper is dedicated to our co-author, the late Naomi P. Mdzeke, who passed away in March 2011 before it was completed. We thank V. Wepener for valuable comments on the manuscript.

\section{REFERENCES}

ANKLEY, G.T., DI TORO, M., HANSEN, D.J. \& BERRY, W.J. 1996. Technical basis and proposal for deriving sediment quality criteria for metals. Environmental Toxicology E Chemistry 15: 2056-2066.

ANON. 1980. The international mussel watch: report of a workshop. National Academy of Sciences, Washington, D.C.

BERVOETS, L. \& BLUST, R. 2000 Effects of pH on Cd and zinc uptake by the midge larvae Chironomus riparius. Aquatic Toxicology 49: 145-157.

BEYER, W.N., HEINZ, G.H. \& REDMON-NORWOOD, A.W. 1996. Environmental Contaminants in Wildife: Interpreting Tissue Concentrations. CRC Publishers, Boca Raton, Florida.

BLACKMORE, G. 1999. Temporal and spatial biomonitoring of heavy metals in Hong Kong coastal waters using Tetraclita squamosa. Environmental Pollution 106: 357-372.

BOURGOIN, B.P. 1990. Mytilus edilus shell as a bioindicator of lead pollution. Considerations on bioavailability and variability. Marine Ecology Progress Series 61: 253-262.

BRANCH, G.M. 1974. The ecology of Patella Linaeus from the Cape Peninsula, South Africa. 2. Reproductive cycles. Transactions of the Royal Society of South Africa 41: 111-160.

BRANCH, G.M. \& CHERRY, M.I. 1985. Activity rhythms of the pulmonate limpet Siphonaria capensis Q. \& G. as an adaptation to osmotic stress, predation and wave action. Journal of Experimental Marine Biology and Ecology 87: 153-168.
BRANCH, G.M., BRANCH, M.L, GRIFFITHS, C.L. \& BECKLEY, L.E. 2005. Two Oceans: A Guide to the Marine Life of Southern Africa. Struik Publishers, Cape Town.

BROWN, A.C. 1987. Marine pollution and health in South Africa. South African Medical Journal 21: 71(4): 244-248.

BU-OLAYAN, A.H., MOHAMMED, H.M.A., SUBRAHMANYAM, M.N.V. \& THOMAS, B.V. 1998. The effect of size upon metal content of the lobster (Thenus orientelis) from Kuwait marine environment. Bulletin of Environmental Contamination \& Toxicology 61: 175-181.

BURGER, J. 2008 Assessment and management of risk to wildlife from Cd. Science of the Total Environment 389: $37-45$.

BURGER, J., DIAZ-BARRIGA, F., MARAFANTA, E., POUNDS, J. \& ROBSON, M. 2003. Methodologies to examine the importance of host factors in bioavailability of metals. Ecotoxicology and Environmental Safety 56: 20-31.

CALABRESE, A., COLLIER, R.S., NELSON, D.A. \& MACINNES, J.R. 1973. The toxicity of heavy metals to embryos of the American oyster Crassostrea virginica. Marine Biology 18: 162-166.

CHINCHON, S., AUERNHEIMER, C., ALASTUEY, A. \& GALI, S. 2000. Accumulation of lead and zinc in sea urchin plates and spines related to their different crystalline structure. Marine Pollution Bulletin 40: 647-649.

CHUNG, K.W., FULLTON, M.H. \& SCOTT, G.I. 2007. Use of the juvenile clam, Mercenaria mercenaria, as a sensitive indicator of aqueous and sediment toxicity. Ecotoxicology and Environmental Safety 67: 333-340.

DABROWSKI, J.M., PEAL, S.K.C., REINECKE, A.J., LIESS, M. \& SCHULZ, R. 2002. Runoff-related pesticide input into the Lourens River, South Africa: basic data for exposure assessment and risk mitigation at the catchment scale. Water, Air and Soil Pollution 135: 265-283.

DARRACOTT, A. \& WATLING, H. 1975. The use of molluscs to monitor $\mathrm{Cd}$ levels in estuaries and coastal marine environments. Transactions of the Royal Society of South Africa 41: 325-338.

DAY, J.H. 1969. Marine Life on South African Shores. Balkema Publisher, Cape Town.

DAY, J. 1970. Biology of False Bay. Transactions of the Royal Society of South Africa 39: 211-221.

DE WOLF, H., BACKELJAU, T. \& BLUST, R. 2000. Heavy metal accumulation in the periwinkle Littorina littorea along a pollution gradient in the Scheldt Estuary. Science of the Total Environment 262: 111-121.

DE WOLF, H., VAN DEN BROECK, H., QADAH, D., BACKELJAU,T. \& BLUST, R. 2005. Temporal trends in soft tissue metal levels in the periwinkle Littorina littorea along the Scheldt Estuary (The Netherlands). Marine Pollution Bulletin 50: 479-484.

FATOKI, C.S. \& MATHABATHA, S. 2001. An assessment of heavy metal pollution in the East London and Port Elizabeth harbours. Water S.A. 27: 233-240.

FIELDER, R.D. \& DALE, E.A. 1983. Cd and its compounds. Toxicity Rev, No. 7. Health and safety executive. Her Majesty's Stationery Office, London. 
GOH, B.P.L. \& CHOU, L.M. 1997. Heavy metal levels in marine sediments of Singapore. Environmental Monitoring \& Assessment 44: 67-80.

GREENFIELD, R., WEPENER, V., DEGGER, N. \& BRINK, K. 2011. Richards Bay Harbour: Metal exposure monitoring over the last 34 years. Marine Pollution Bulletin 26: $1926-1931$.

GRINDLEY, J.R. \& TAYLOR, FJ.R. 1970. Factors affecting plankton blooms in False Bay. Transactions of the Royal Society of South Africa. 39: 201-210.

GRIFFITHS, C. \& BRANCH, G.M. 1991. The macrofauna of rocky shores in False Bay. Transactions of the Royal Society of South Africa 47: 575-594.

HEINECKEN, T.J.E., BICKERTON, I.B. \& HEYDON, A.E.F. 1983. A summary of studies of the pollution input of rivers and estuaries entering False Bay. CSIR Report/ SEA 8031, Stellenbosch.

HERWIG, H.J., BRANDS, F., KRUITWAGEN, E. \& ZANDEE, D.E. 1989. Bioaccumulation and histochemical localization of cadmium in Dreissena polymorpha exposed to cadmium chloride. Aquatic Toxicology 15: 269-286.

HOPS, J.M. 1990. Effect of industrial and domestic effluents on the settlement, growth, reproduction and mortality of the brown mussel Perna perna in the outlet of the Papenskuil River, Algoa Bay, South Africa. M.Sc. thesis, University of Port Elizabeth, Port Elizabeth, South Africa.

HUCKABEE, J.W. \& BLAYLOCK, B.G. 1973. Transfer of mercury and cadmium from terrestrial to aquatic ecosystems. In: Metal Ions in Biological Systems, (ed.) S.K. Dhar, pp. 125-160. Plenum Press, New York.

IRELAND, M.P. 1974. Variations in the zinc, copper, manganese and lead content of Balanus balanoides in Cardigan Bay, Wales. Environmental Pollution 7: 65-75.

KATZ, S.A. \& JENNIS, S.W. 1983. Regulatory Compliance Monitoring by Atomic Absorption Spectroscopy. Verlag Chemie International, Deerfield Beach, Florida

KIFFNEY, P.M. \& CLEMENTS, W.M. 1993. Bioaccumulation of heavy metals by benthic invertebrates at the Arkansas River, Colorado. Environmental Toxicology \& Chemistry 12: 1507-1517.

LEUVEN, R.S.E.W., DEN HARTOG, C., CHRISTIAANS, M.M.C. \& HEIJILIGERS, W.H.C.I. 1986. Effects of water acidification on the distribution pattern and reproductive success of amphibians. Experentia 42: 495-503.

LOBEL, P.B., MOGIE, P., WRIGHT, D.A \& WU, B.L. 1982. Metal accumulation in four molluscs. Marine Pollution Bulletin 13: 170-174.

MARTIN, M., OSBORN, K.E., BILLIG, P. \& GLICKSTEIN, N. 1981 Toxicities of ten metals to Crassostrea gigas and Mytilus edulis embryos and Cancer magister larvae, Marine Pollution Bulletin 12: 183-188.

MDZEKE, N.P. 2004. Contamination levels in and cellular responses of intertidal invertebrates as biomarkers of toxic stress caused by heavy metal contamination in False Bay. Ph.D. thesis, University of Stellenbosch, Stellenbosch, South Africa.

MIRAMAND, P., BUSTAMANTE, P., BENTLEY, D. \& KOUÉTA, N. 2006. Variation of heavy metal concentrations (Ag, Cd, $\mathrm{Co}, \mathrm{Cu}, \mathrm{Fe}, \mathrm{Pb}, \mathrm{V}, \mathrm{Zn}$ ) during the life cycle of the common cuttlefish Sepia officinalis. Science of the Total Environment. 361: 132-143.
MUBIANA, V.K., QADAH, D., MEYS, J. \& BLUST, R. 2005. Temporal and spatial trends in heavy metal concentrations in the marine mussel Mytilus edulis from the Western Scheldt estuary (the Netherlands). Hydrobiologia 540: 169-180.

NASSIRI, Y., WERY, J., MANSOT, J.L., GINSBURGERVOGEL, T. 1997. Cadmium bioaccumulation in Tetraselmis suecica: an electron energy loss spectroscopy (EELS) study. Archives of Environmental Contamination and Toxicology 33: 156-161.

NEAL, C., JARVIE, H.P., WHITTON, B.A. \& GEMMELL, J. 2000. The water quality of the River Wear, northeast England. Science of the Total Environment 251: 153-172.

O'DONOGHUE, S. \& MARSHALL, D.J. 2003. Marine pollution research in South Africa: a status report. South African Journal of Science 99: 349-356.

POSTHUMA, L., EIJSACKERS, H. \& VIJVER, M. 2006. Toxische stoffen, normen en ecologische risico's hoe zit dat? Milieu Dossier 7: 19-23.

POWELL, M.I. \& WHITE, K.N. 1990. Heavy metal accumulation by barnacles and its implication for their use as biological monitors. Marine Environmental Research 30: 91-118.

OVA, V., KOMAREK, J., DUSEK, L. \& HOLOUBEK, I. 2003. Mobility, bioavailability, and toxic effects of cadmium in soil samples. Environmental Research 91: 119-126.

PAEZ-OSUNA, F., FRIAS-ESPERICUETA, M.G. \& OSUNA-LOPEZ, J.I. 1995. Trace metal concentration in relation to season and gonadal maturation in the oyster Crassostrea iridescens. Marine Environmental Research 40: 19-31.

RAINBOW, P.S. 1995. Biomonitoring of heavy metal availability in the marine environment. Marine Pollution Bulletin 31: 183-192.

RAINBOW, P.S. 1997. Trace metal accumulation in marine invertebrates: marine biology or marine chemistry? Journal of Marine Biological Association 77: 195-210.

RAINBOW, P.S. 2002. Trace metal concentrations in aquatic invertebrates: why and so what? Environmental Pollution 120: 497-507

RAINBOW, P.S., WOLOWICZ, M., FIALKOWSKI, W., SMITH, B.D. \& SOKOLOWSKI, A. 2000. Bio-monitoring of trace metals in the Gulf of Gdansk using mussels (Mytilus trossulus) and barnacles (Balanus improvisus). Water Research 34: 1823-1829.

RAMELOW, G.T. 1985. A study of heavy metals in limpets (Patella sp.) collected along a section of the southeastern Turkish Mediterranean Coast. Marine Environmental Research 16: 243-253.

REGOLI, F. 1998 Trace metals and antioxidant enzymes in gills and digestive gland of the Mediterranean mussel Mytilus galloprovincialis. Archives of Environmental Contamination and Toxicology 34: 48-63.

REGOLI, F., ORLANDO, E., MAURI, M., NIGRO, M., COGNETTI, G.A., 1991. Heavy metal accumulation and calcium content in the bivalve Donacilla cornea. Marine Ecology Progress Series 74: 219-224.

REINECKE, A.J., MDZEKE, N.P. \& REINECKE, S.A. 2009. Cadmium in False Bay: uptake, distribution and excretion by the marine snail, Oxystele tigrina (Mollusca). Suid-Afrikaanse Tydskrif vir Natuurwetenskap en Tegnologie 28: 101-118. 
REINECKE, A.J., SCHOEMAN, W. \& REINECKE, S.A. 2008. Cellular biomarker responses of limpets (Mollusca) as measure of sensitivity to cadmium contamination. Suid-Afrikaanse Tydskrif vir Natuurwetenskap en Tegnologie 27: 123-142.

RUELAS-INZUNZA, J. \& PAEZ-OSUNA, F. 1998. Barnacles as biomonitors of heavy metal pollution in the coastal waters of Mazatlan Harbor (Mexico). Bulletin of Environmental Contamination $\mathcal{E}$ Toxicology 61: 608-615.

SCHULZ-BALDES, M. 1974. Lead uptake from seawater and food and lead loss in the common mussel Mytilus edulis. Marine Biology 25: 177-193.

SEIXAS, S., BUSTAMANTE, P. \& PIERCE, G.J. 2005. Accumulation of mercury in the tissues of the common octopus Octopus vulgaris (L.) in two localities on the Portuguese coast. Science of the Total Environment 340: 113-122.

SHORE, R., CARNEY, G. \& STYGALL, T. 1975. Cadmium levels in carbohydrate metabolism in limpets. Marine Pollution Bulletin 12: 187-189.

TALJAARD, S., VAN BALLENGOOYEN, R.C. \& MORANT, P.D. 2000. False Bay Water Quality Review. CSIR Report Env-S-C-2000-086/1, Stellenbosch.

VAN DER MERWE, I.J., VLOK, A-C. \& VAN DER MERWE, J.H. 1991. Land use and population charac- teristics in the False Bay coastal frame. Transactions of the Royal Society of South Africa 47: 693-702.

VERMEULEN, L. \& WEPENER, V. 1999. Spatial and temporal variations of metals in Richards Bay harbour, South Africa. Marine Pollution Bulletin 39: 304-307.

VILLANUEVA, R. \& BUSTAMANTE, P. 2006. Composition in essential and non-essential elements of early stages of cephalopods and dietary effects on the elemental profiles of Octopus vulgaris para larvae. Aquaculture 261: 225-240.

WARNAU, M., IACCARINO, M., DE BIASE, A., TEMARA, A., JANGOUX, M., DUBOIX P.H. \& G. PAGANO, G. 1996. Spermiotoxicity and embryotoxicity of heavy metals in the echinoid Paracentrotus lividus. Environmental Toxicology and Chemistry 15: 1931-1936.

WEPENER, V., BERVOETS, L., MUBIANA, V. \& BLUST, R. 2008. Metal exposure and biological responses in resident and transplanted blue mussels (Mytilus edulis) from the Scheldt estuary. Marine Pollution Bulletin 57: 624-631

ZHANG, W. FENG, H. CHANG, J, QU, J., XIE, H. \& YU, L. 2005. Heavy metal contamination in surface sediments of Yangtze River intertidal zone: an assessment from different indexes. Environmental Pollution 157: 1533-1543. 